\title{
Environmental Education outside school: effects of a half-day teaching programme
}

\author{
Jürgen Drissner ${ }^{1}$, Marie-Luise Steigmüller ${ }^{1}$, Katrin Hille ${ }^{2}$ \\ ${ }^{1}$ Botanical Garden, University of Ulm, D - 89081 Ulm, Germany \\ ${ }^{2}$ Transfercenter for Neuroscience and Learning, University of Ulm, Germany
}

Email address:

juergen.drissner@uni-ulm.de (J. Drissner)

To cite this article:

Jürgen Drissner, Marie-Luise Steigmüller, Katrin Hille. Environmental Education Outside School: Effects of a Half-Day Teaching Programme. Education Journal. Vol. 2, No. 6, 2013, pp. 231-235. doi: 10.11648/j.edu.20130206.14

\begin{abstract}
The "Green Classroom" in the Botanical Garden of the University of Ulm is a learning forum outdoor school that is used by about 2,500 school students annually. Its educational concept is based on experiential learning and is geared towards expanding students' biological knowledge and awareness of small animals such as invertebrates and insects. In the first study, 66 students (grade 4) were asked to draw a picture of a pond as a habitat. 33 of these students had previously visited the "Green Classroom" (intervention group). Students of the intervention group drew more of the smaller types of animals in their pictures and furthermore a bigger variety of species of animals and plants than the control group. In the second study, the same students (66, grade 4) were given a list of animal species, and were asked to tick those which are typical to a pond. Students who had visited the "Green Classroom" ticked more animals off correctly than their peers in the control group.
\end{abstract}

Keywords: Learning Outside School, Small Animals (Invertebrates, Insects), Knowledge about Small Animals, Experiential Learning

\section{Introduction}

When children are asked to list the species they know, they generally talk about animals that are not found in their own environment (Lock, 1995). Vertebrates -seemingly more remarkable and extraordinary- are mentioned, whereas small animals (invertebrates and insects) are hardly ever discussed (Kellert, 1993; Snaddon et al, 2008). Small animals receive little attention from media in comparison to birds or large vertebrates (Lock, 1995; Snaddon and Turner 2007; Snaddon et al, 2008). The majority of invertebrates are harmless and crucial for our ecological system (Wilson, 1987). Moreover, many of them are classed as endangered species or on the brink of extinction (Wilson, 1987; Bixler et al, 1999; Wagler and Wagler, 2011). This extinction has been dramatically accelerating, and it is difficult to predict the outcome (Rockström et al, 2009).

If children are not familiar with the animals of their own natural environment, they will find it difficult to address issues of biodiversity and ecological problems (Weilbacher, 1993; Heywood, 1995). In a nutshell, if children are not even aware of small animals how can these be protected for future generations?
Against this background many authors (Kellert, 1993; Bixler et al, 1999; Snaddon and Turner 2007; Snaddon et al, 2008; Wagler and Wagler, 2011) argue for raising young peoples' awareness and knowledge of small animals.

Opinions about the relationship between knowledge on the one hand and ecological awareness on the other hand, vary considerably. However, many researchers assume that an important positive relationship actually exists (Bogner, 1998; Kaiser et al, 1999; Barraza and Walford, 2002; DiEnno and Hilton, 2005). The rationale behind this assumption is that 'we can only protect what we know'. Furthermore, we can only miss a species if we have had some kind of attachment to it (Weilbacher, 1993; Fawcett, 2002; Lindemann-Matthies, 2002).

Studying nature outside of the classroom is regarded by some scholars as the most effective and, at the same time, the most pleasurable way of teaching children about various species and biodiversity (Lock, 1995; Lindemann-Matthies, 2006). Several scientists also emphasize the relevance of the active process of learning about diversity in natural habitats (e.g. Mayer, 1992; Chawla, 1998; de Haan, 2005). Furthermore, biology lessons can be made more enjoyable by studying living plants and animals first-hand (Lock, 1998; 
Barker et al, 2002). Direct contact with nature helps to enhance ecological awareness, positive environmental attitudes and a caring approach towards living creatures (Yore and Boyer, 1997; Lock, 1998; Fawcett, 2002; Haase, 2003).

The curriculum of the "Green classroom" was established 15 years ago at the University of Ulm in order to address this background.

\subsection{The "Green Classroom"-Approach, Curriculum}

With the above-mentioned ideas in mind, learning in the "Green Classroom" is organised in such a way that students encounter animals in their natural habitat, and what they observe will be explained and put into context. Questions that arise from these encounters will be addressed immediately. The topics that students deal with in the "Green Classroom" are topics about small animals that can be found in the environment of the children. The Botanical Garden allows students to explore the animals in their original habitat, e.g. meadow, forest and pond. Students are taught about the habitat and its importance as well as about how to deal respectfully with the animals that live there. After that students explore the habitat and carefully catch animals in special small boxes. These boxes will be taken to the "Green Classroom" that is integrated in all the habitats listed above. There the animals will be observed through magnifying glasses. While working with the small animals, scientific information is presented in order to introduce specific small animals and possibly initiate 'personal relationships'. Students will be asked to produce, depending on their age, drawings of animals themselves or of their food chains and habitats. Observations in the "Green Classroom" show that students begin to empathise and care for these animals in this process. For further information see (www.uni-ulm.de/einrichtungen/garten/gruenes-klassenzim mer.html) or Drissner et al. 2010.

Some of the goals of the "Green Classroom" (e.g. to expand knowledge and awareness of especially small animals in our own environment) were evaluated in this study. In previous studies we have shown that the "Green Classroom" has short-term effects on children's attitudes towards small animals, and motivates them to learn more about these animals (Drissner et al, 2008, 2010, 2011). This study investigates if the "Green Classroom" creates long-term effects on awareness and knowledge of these animals.

\section{Study 1}

\subsection{Participants}

The sample comprised 66 elementary school students (grade 4). The students were recruited from 2 different schools in south-western Germany. In each school there was a class of students that became part of the intervention group and a class that became part of the control group. 33 of the students ( 8 girls, 25 boys) formed the control group. The 33 other students (15 girls, 18 boys) from the same school and same grade served as intervention group and attended the "Green Classroom" for one morning. This visit took place up to 4 months before the study was carried out (min. 3, max. 4 months).

\subsection{Measures and Design}

The elementary school children were asked to draw pictures. A drawing task is used to exclude the influence of writing competence on assessing what animals children know (Reiss and Tunnicliffe, 2001). The drawing task was set up to assess if school children are aware of small animals (e.g. invertebrates) - as this was the goal of the intervention. It is not important that invertebrates are drawn correctly (Reiss et al, 2007), but that they are drawn at all.

At school during regular class both groups of students were asked to draw a picture of a pond as a habitat, with typical plants and animals that they knew.

The drawings (Figure 1 and 2 show two examples) were evaluated in terms of the following criteria:

(1) number of small animals (e.g. insects, invertebrates): e.g. water scorpion, ramshorn snail, dragonfly, great pond snail

(2) number of large animals (vertebrates): e.g. stickleback, water frog, common toad

(3) total number of different animal-species

(4) total number of different plant-species: e.g. cattail, reed

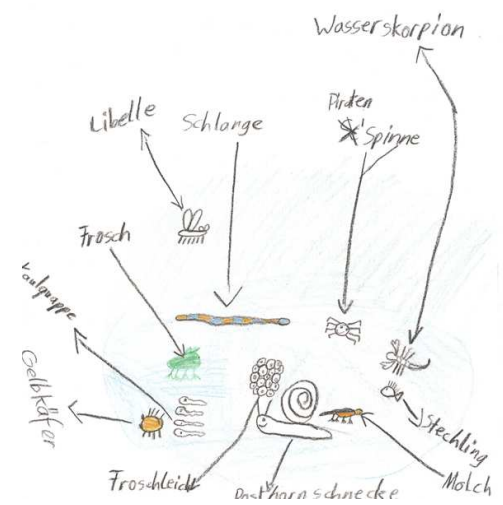

Figure 1. Picture of a pond, drawn by a student of the intervention group; small animals: water scorpion, ramshorn snail, wolf spider (Pirata piraticus), dragonfly, tadpole, salamander (larva), great diving beetle; large animals: stickleback, snake, frog

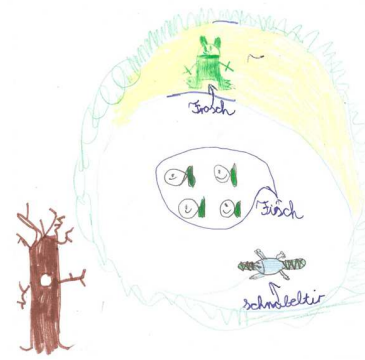

Figure 2. Picture of a pond, drawn by a student of the control group; small animals: none; large animals: fish, frog, (platypus not assessed);plants: tree, grasses 


\subsection{Results}

Students of the intervention group drew four times as many small animals and a higher diversity of animals and plants in their pictures than the control group. Results showed that the girls in the intervention group drew a larger variety of plants than the girls of the control group. Furthermore the boys of the intervention group drew a larger variety of plants and many more small animals than the boys in the control group. Detailed results are presented in Table 1 .

Table 1: Number of plants and animals drawn. Means for the intervention group and the control group (Mann-Whitney-U-test)

\begin{tabular}{|c|c|c|c|c|c|c|}
\hline & \multicolumn{2}{|c|}{ intervention group } & \multicolumn{2}{|c|}{ control group } & \multirow{2}{*}{$\begin{array}{l}\text { corrected } \\
\text { z-value }\end{array}$} & \multirow{2}{*}{ p-level } \\
\hline & $M[95 \% C I]$ & $S D$ & $M[95 \% C I]$ & $S D$ & & \\
\hline \multicolumn{7}{|c|}{ Number of small animals (insects, invertebrates) } \\
\hline all & $2.12[1.40$ to 2.85$]$ & 2.04 & $0.52[0.22$ to 0.81$]$ & 0.83 & 3.50 & $0.000 * * *$ \\
\hline girls & $1.93[0.90$ to 2.97$]$ & 1.87 & $0.75[-0.22$ to 1.72$]$ & 1.16 & 3.50 & 0.088 \\
\hline boys & $2.28[1.17$ to 3.38$]$ & 2.22 & $0.44[0.15$ to 0.73$]$ & 0.71 & 2.66 & $0.007 * *$ \\
\hline \multicolumn{7}{|c|}{ Number of large animals (vertebrates) } \\
\hline all & $2.18[1.68$ to 2.69$]$ & 1.42 & $1.73[1.09$ to 2.36$]$ & 1.79 & 1.29 & 0.194 \\
\hline girls & $2.60[1.88$ to 3.32$]$ & 1.30 & $1.50[-0.23$ to 3.23$]$ & 2.07 & 1.58 & 0.114 \\
\hline boys & $1.83[1.10$ to 2.56$]$ & 1.47 & $1.80[1.09$ to 2.51$]$ & 1.73 & 1.27 & 0.899 \\
\hline \multicolumn{7}{|c|}{ Number of different animal species } \\
\hline all & $4.30[3.10$ to 5.97$]$ & 2.95 & $2.27[1.42$ to 3.13$]$ & 2.41 & 2.83 & $0.005 * *$ \\
\hline girls & $4.53[3.26$ to 5.35$]$ & 2.59 & $2.25[-0.38$ to 4.88$]$ & 3.15 & 1.69 & 0.090 \\
\hline boys & $4.11[2.48$ to 5.75$]$ & 3.29 & $2.28[1.37$ to 3.19$]$ & 2.21 & 1.87 & 0.060 \\
\hline \multicolumn{7}{|c|}{ Number of different plant species } \\
\hline all & $2.30[1.90$ to 2.70$]$ & 1.13 & $0.64[0.33$ to 0.94$]$ & 0.86 & 5.53 & $0.000 * * *$ \\
\hline girls & $2.47[1.69$ to 3.25$]$ & 1.41 & $1.00[-0.09$ to 2.09$]$ & 1.31 & 2.34 & $0.020 *$ \\
\hline boys & $2.17[174$ to 2.59$]$ & 0.86 & $0.52[0.25$ to 0.79$]$ & 0.65 & 4.88 & $0.000 * * *$ \\
\hline
\end{tabular}

$* \mathrm{p}<0,05 ; * * \mathrm{p}<0,01 ; * * * \mathrm{p}<0,001$

Table 2: Number of correctly and incorrectly ticked animals. Means for the intervention group and the control group (Mann-Whitney-U-test)

\begin{tabular}{|c|c|c|c|c|c|c|}
\hline & \multicolumn{2}{|c|}{ intervention group } & \multicolumn{2}{|c|}{ control group } & \multirow{2}{*}{$\begin{array}{c}\text { corrected } \\
\text { z-value }\end{array}$} & \multirow{2}{*}{ p-level } \\
\hline & $M[95 \% C I]$ & $S D$ & $M[95 \% C I]$ & $S D$ & & \\
\hline all & $6.52[6.12$ to 6.91$]$ & 1.12 & $3.39[2.91$ to 3.88$]$ & 1.37 & 6.44 & $0.000 * * *$ \\
\hline girls & $6.47[6.00$ to 6.93$]$ & 0.83 & $3.12[2.08$ to 4.17$]$ & 1.25 & 3.83 & $0.000 * * *$ \\
\hline boys & $6.55[5.89$ to 7.22$]$ & 1.34 & $3.48[2.89$ to 4.07$]$ & 1.42 & 4.92 & $0.000 * * *$ \\
\hline \multicolumn{7}{|c|}{ Number of incorrectly ticked animals } \\
\hline all & $3.45[2.94$ to 3.97$]$ & 1.46 & $7.12[6.64$ to 7.60$]$ & 1.36 & -6.42 & $0.000 * * *$ \\
\hline girls & $3.20[2.50$ to 3.90$]$ & 1.26 & $7.25[5.85$ to 8.65$]$ & 1.67 & -3.60 & $0.000 * * *$ \\
\hline boys & $3.67[2.87$ to 4.47$]$ & 1.61 & $7.08[6.55$ to 7.61$]$ & 1.29 & -4.95 & $0.000 * * *$ \\
\hline all & $3.06[2.22$ to 3.91$]$ & 2.38 & $-3.79[-4.61$ to -2.71$]$ & 2.32 & 6.61 & $0.000 * * *$ \\
\hline girls & $3.27[2.17$ to 4.36$]$ & 1.98 & $-4.13[-6.15$ to -2.10$]$ & 2.42 & 3.71 & $0.000 * * *$ \\
\hline boys & $2.89[1.54$ to 4.24$]$ & 2.72 & $-3.68[-4.64$ to -2.97$]$ & 2.32 & 5.08 & $0.000 * * *$ \\
\hline
\end{tabular}

$* * * \mathrm{p}<0,001$ 


\section{Study 2}

\subsection{Participants}

Same sample (see Study 1).

\subsection{Measures and Design}

The school children were asked to tick animals off a list which are typical to a pond. This assignment was part of a regular lesson. The following species were listed: ramshorn snail (correct: should be ticked off by the students), day gecko (incorrect: should not be ticked off by the students), dragonfly (correct), water scorpion (correct), soldier beetle (incorrect), stickleback (correct), corn snake (incorrect), dumpy tree frog (incorrect), wolf spider (Pirata piraticus, correct), clownfish (incorrect), great pond snail (correct), pea cockle (correct), striped stink bug (incorrect), water frog (correct), common toad (correct), millipede (incorrect).

The questionnaire included nine correct species, which are typical pond species, and seven incorrect species which are not typically found in German ponds.

\subsection{Results}

Students of the intervention group ticked more than twice as many animal-species correctly than the control group, whereas the control group ticked twice as many species incorrectly compared to the intervention group. The students of the intervention group had a better knowledge (difference between correctly and incorrectly marked species) of typical species found in a pond. Detailed results are presented in Table 2.

\section{Discussion and Conclusion}

The positive results (e.g. better knowledge and raised awareness of small animals and plants) noted in the intervention group but not in the control group are remarkable considering the duration of the visit. The students only attended the "Green Classroom" for half a day. This is extremely short-term participation. According to other studies conducted to date, short-term participation takes at least a few days, possibly even weeks, in order to have any impact (e.g. Bogner, 1998; Haase, 2003; Rideout, 2005). So far, it has been assumed that environmental programmes aiming to be effective need to be continued for at least several days. It has been recommended that programmes of several days duration be initiated in order to create effective changes (Bogner, 1998). The fact that some positive changes have been recorded from a half-day teaching-programme could reflect the importance of the educational work in a learning forum outside school. Half-day teaching programmes are an important part of experiential learning outside the classroom. Such short programmes can be more easily integrated into the curricula, and they can be prepared for and reflected on accordingly by the students within the classroom setting.

Children who attended the "Green classroom" drew more small animals and more species (animals and plants) in comparison to children of the control group. In the control group we noticed that children are more aware of large animals than of small animals: a pattern described by Lock (1995). This in turn suggests a raised awareness of small animals due to the visit in the "Green classroom".

While intention of the programme was to bring about a change, it cannot be taken for granted that the "Green Classroom"-experience must necessarily bring about a better knowledge and a higher awareness of e.g. small animals. Drissner et al $(2008,2011,2013)$ shows that after visiting the "Green Classroom", students perceive small animals e.g. as more fascinating, more useful, more valuable, more harmless, more worth protecting, and cuter. In general, the students liked the animals better after the intervention. No such changes were found in the control group. Furthermore Drissner et al $(2008,2013)$ could show in two similar studies that differences in knowledge and emotions of students who did or did not visit the "Green Classroom" could be found years after the visit. The students who had visited the "Green Classroom" demonstrated better knowledge of and more positive emotions towards small animals, even though it had been five years since the visit for some of the students. These results support the importance of an emotional learning (see also Helmke, 1993, Hascher 2005, Guarino et al 2010).

The intrinsic motivation of students to interact with small animals and find them fascinating could provide a sound basis for generating further interest in fauna. It could be presumed that contact with the small animals encountered in the "Green Classroom" environment triggers students' interest and approach towards small animals, subsequently establishing a more positive attitude towards these animals. This rise of intrinsic motivation, shown by Drissner et al (2010), could help explain the positive changes found in the intervention group. The students who visited the "Green Classroom" later reported that they enjoyed learning about small animals more than before.

The results of both studies taken together suggest that the outdoor setting of an educational programme can have a valuable formative influence, helping to develop a better knowledge of specific animals and create a greater awareness.

\section{References}

[1] Lock, R. (1995). Biology and the environment - A changing perspective? Or "there's wolves in them there woods!" Journal of Biological Education. 29 3-4.

[2] Kellert, S. R. (1993). Values and perceptions of invertebrates. Conservation Biology. 7 845-855.

[3] Snaddon, J. L., Turner, E. C., and Foster, W. A. (2008). Children's perceptions of rainforest biodiversity: Which 
animals have the lions's share of environmental awareness? PLoS ONE. 3/7 e2579 1-5.

[4] Snaddon, J. L. and Turner, E. C. (2007). A child's eye view of the insect world: perceptions of insect diversity. Environmental Conservation. 34 33-35.

[5] Wilson, E. (1987). Little things that run the world. Conservation Biology. 1 344-346.

[6] Bixler, R. D., Floyd, M. F. and Myron, F. (1999). Hands on or hands off? Disgust sensitivity and preference for Environmental Education activities. The Journal of Environmental Education. 30 4-11.

[7] Wagler, R. and Wagler, A. (2011). Arthropods: Attitude and incorporation in preservice elementary teachers. International Journal of Environmental \& Science Education. 6(3) 229-250.

[8] Rockström, J., Steffen, W., Noone, K., Persson, A., Chapin, F. S., Lambin, E. F., Lenton, T. M., Scheffer, M., Folke, C., Schellnhuber, H. J., Nykvist, B., de Wit, C. A., Hughes, T., van der Leeuw, S., Rodhe, H., Sörlin, S., Snyder, P. K., Costanza, R., Svedin, U., Falkenmark, M., Karlberg, L., Corell, R. W., Fabry. V. J., Hansen, J., Walker, B., Liverman, D., Richardson, K., Crutzen, P., and Foley, J. A. (2009). A safe operating space for humanity. Nature. 461 472-475.

[9] Weilbacher, M. (1993). The renaissance of the naturalist. The Journal of Environmental Education. 25 4-7.

[10] Heywood, V. H. (1995). Global biodiversity assessment. Cambridge: Cambridge University Press.

[11] Bogner, F. X. (1998). The influence of short-term outdoor ecology education on long-term variables of environmental perspective. The Journal of Environmental Education. 29 $17-29$.

[12] Kaiser, F. G., Wolfing, S., and Fuhrer, U. (1999). Environmental attitude and ecological behaviour. Journal of Environmental Psychology. 19 1-19.

[13] Barraza, L. and Walford, R. A. (2002). Environmental Education: A comparison between English and Mexican school children. Environmental Education Research. 8 171-186.

[14] DiEnno, C. M. and Hilton, S. C. (2005). High school students' knowledge, attitudes and levels of enjoyment of an Environmental Education Unit on nonnative plants. Journal of Environmental Education. 37 13-25.

[15] Fawcett, L. (2002). Children's wild animal stories: questioning inter-species bonds. Canadian Journal of Environmental Education. 7(2) 125-139.

[16] Lindemann-Matthies, P. (2002). The influence of an educational programme on children's perception of biodiversity. The Journal of Environmental Education. 33 22-31.

[17] Lindemann-Matthies, P. (2006). Investigating nature on the way to school: Responses to an educational programme by teachers and their pupils. International Journal of Science Education. 28(8) 895-918.

[18] Mayer, J. (1992). Formenvielfalt im Biologieunterricht. Kiel.

[19] Chawla, L. (1998). Significant life experiences revisited: a review of research on sources of Environmental Sensitivity.
Journal of Environmental Education. 29 11-23.

[20] Haan, G. de (2005). Vorwort. In J. Kandeler, Kinder lernen Umwelt schützen, Handbuch für Umweltpädagogik in Kindergarten und Grundschule. Berlin: Natur und Umwelt.

[21] Lock, R. (1998). Fieldwork in the life sciences. International Journal of Science Education. 20 633-642.

[22] Barker, S., Slingsby, D. and Tilling, S. (2002). Ecological fieldwork: Is there a problem? Environmental Education. 71 9-10.

[23] Yore, L. B. and Boyer, S. (1997). College students' attitudes towards living organisms: The influence of experience \& knowledge. The American Biology Teacher. 59 558-563.

[24] Haase, H.-M. (2003). Worldrangers: Ein pädagogischer Beitrag für eine nachhaltige Entwicklung. Hintergründe und Praxisvorschläge für eine zeitgemäße Umweltbildung. Hamburg: Dr. Kovac.

[25] Drissner, J., Haase, H.-M. and Hille, K. (2010). Short-term Environmental Education - Does it work? -An evaluation of the "Green Classroom". Journal of Biological Education. 44 (4) $149-155$.

[26] Drissner, J., Hille, K., Debatin, S. and Haase, H.-M. (2008). Das Grüne Klassenzimmer im Botanischen Garten der Universität Ulm - eine Wirkungsanalyse. Diskurs Kindheitsund Jugendforschung. 2 209-218.

[27] Drissner, J., Haase, H.-M., Nikolajek, M. and Hille, K. (2011). Environmental Education in a Green Classroom. Resonance Journal of Science Education. 16(2) 180-187.

[28] Reiss, M. J. and Tunnicliffe, S. D. (2001). Students' Understandings of Human Organs and Organ Systems. Research in Science Education. 31 383-399.

[29] Reiss, M., Boulter, C., and Tunnicliffe, S. D. (2007). Seeing the natural world: a tension between pupils' diverse conceptions as revealed by their visual representations and monolithic science lessons. Visual Communciation. Vol.6 1 $99-114$.

[30] Rideout, B. E. (2005). The effect of a brief environmental problems module on endorsement of the new ecological paradigm in college students. The Journal of Environmental Education. 37 3-11.

[31] Drissner, J., Haase, H.-M., Rinderknecht, A., Hille, K. (2013) "Effective Environmental Education through Half-Day Teaching Programmes Outside School," ISRN Education, vol. 2013, Article ID 503214, 6 pages, 2013. doi: $10.1155 / 2013 / 503214$

[32] Helmke, A. (1993). Die Entwicklung der Lernfreude vom Kindergarten bis zur 5. Klassenstufe. Zeitschrift für Pädagogische Psychologie. 7 77-86.

[33] Hascher, T. (2005). Emotionen im Schulalltag: Wirkungen und Regulationsformen. Zeitschrift für Pädagogik. 5 610-625.

[34] Guarino, R., Menegoni, P., Pignatti, S. (2010). "Educational or emotional languages? An interactive experiment with the Lucanian flora (S-Italy)". In: Nimis P.L. and Vignes Lebbe R. (eds.): Tools for identifying biodiversity: progress and problems. 405-409. 